\title{
内視鏡支援下での顎関節突起骨折に対する観血的整復固定術の臨床的検討
}

\author{
谷池直樹 ${ }^{1)}$ ・竹信 俊彦 ${ }^{1)} \cdot$ 山田剛 也 ${ }^{2)}$ ・高橋 淳 ${ }^{1)}$ \\ 上原京憲 ${ }^{1)} \cdot$ 朴 成泰 ${ }^{1)} \cdot$ 藤井智子 1 ) \\ 西田哲也 ${ }^{1)} \cdot \mathrm{E}^{2}$ 野紀也 $^{1)} \cdot$ 田中義弘 ${ }^{1)}$
}

\section{Clinical study of endoscopically assisted open reduction and internal fixation for condylar fractures of the mandible}

\author{
TANIIKE Naoki ${ }^{1)} \cdot$ TAKENOBU Toshihiko $^{1)} \cdot$ YAMADA Takeya $^{2)}$ \\ TAKAHASHI Atsushi ${ }^{1)} \cdot$ UEHARA Kyonori $^{1)} \cdot$ PARK Seong-tae $^{1)}$ \\ FUJII Tomoko ${ }^{1)} \cdot$ NISHIDA Tetsuya ${ }^{1 \text { ) }}$ \\ NAGANO Michiya $^{1)} \cdot$ TANAKA Yoshihiro ${ }^{1)}$
}

\begin{abstract}
We successfully used an endoscope to assist in the repair of mandibular condylar fractures in 12 patients from August 2006 through October 2007. Their ages ranged from 16 to 68 years, with an average of 35 years. All patients presented with unilateral condylar fractures. Seven of the 12 patients additionally had mandibular fractures.

A 4.0-mm, 30-degree angled endoscope was introduced to visualize the fracture site by means of an intraoral incision over the ascending ramus. A 2.0-mm titanium miniplate and screws were used to stabilize the fracture site with the help of a percutaneous trocar. The use of an angled endoscope provided a good view of the fracture site, permitting precise anatomical reduction.

All patients had a stable occlusion in the postoperative period, and anatomic alignment of the condyle was confirmed radiographically. There was no persistent facial palsy.

The benefits of using this endoscopically assisted technique include not only the provision of better visualization and precise anatomic alignment of bony segments, but also the avoidance of facial nerve injuries and large facial scars.
\end{abstract}

Key words: endoscopically assisted surgery（内視鏡支援下手術）， condylar fractures of the mandible（顎関節突起骨 折), transoral surgical treatment（口腔内アプローチ手術）

緒言

買関節突起骨折の治療に関しては多くの報告があり，大 きく観血的治療と非観血的治療の二つに分類される ${ }^{1,2)}$.

1) 神戸市立医療センター中央市民病院菌科口腔外科 （主任：田中義弘部長）

2) 彦根市立病院菌科口腔外科 (主任：山田剛也医長)

${ }^{1)}$ Department of Oral and Maxillofacial Surgery, Kobe City Medical Center General Hospital (Chief: Dr. TANAKA Yoshihiro)

${ }^{2)}$ Department of Oral and Maxillofacial Surgery, Hikone Municipal Hospital (Chief: Dr. YAMADA Takeya)

受付日：2008年 8 月 6 日

採択日：2009年 6 月 23 日
その選択はいまだ意見の分かれるところであるが，さまざ まな手術手技や器具の開発により観血的治療を積極的に行 う施設も増加している. 近年は口腔内切開からのアプロー チで内視鏡支援下での観血的整復固定術（Endoscopically assisted open reduction and internal fixation ; 以下 EAORIF）を行い, 良好な結果が得られたとの報告も海外 を中心に散見される ${ }^{3,4)}$.

われわれもすでに顎関節突起基底部骨折にEAORIFを 行い良好な結果が得られた症例について報告している ${ }^{5)}$. 今回われわれはその後さらに 12 例の顎関節突起骨折に EAORIFを適用し, その結果を機能的, 形態的に評価, 検 討したので報告する. 


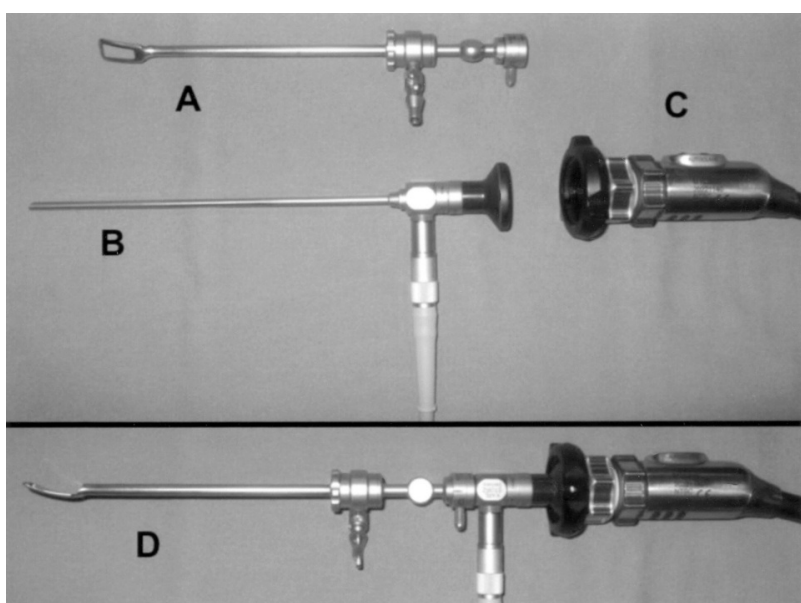

写真 1 内視鏡セット

A：内視鏡ホルダー付きディセクター (Optical Dissector, KARL STORZ 社製)

B : 30 度の角度付き硬性鏡 (Wide Angle ForwardOblique Telescope $30^{\circ}$, KARL STORZ 社製）に光源 を接続した状態

C : 内視鏡カメラ (Endovision TRICAM SL II , KARL STORZ 社製)

D ：A, B, C を接続した状態

\section{使 用 器 具}

内視鏡は $4.0 \mathrm{~mm}$ 径, 30 度の角度付き硬性鏡（Wide Angle Forward-Oblique Telescope $30^{\circ}$, KARL STORZ 社 製）に, EAORIF 専用の内視鏡ホルダー付きディセクター (Optical Dissector, KARL STORZ 社製）を装着し使用した (写真 1).ホールディングチップ付きプレートイントロデ ユーサーや近位骨片整復時に用いる骨把持鉗子, 角度付き 剥離子などの特殊器具は㖽関節突起骨折の EAORIF 専用 に開発された Subcondylar/Ramus Fixation Set（SYNTHES 社製）内のものを使用した（写真 2 ).

\section{手 術 方 法}

術中の立ち位置は, 術者が患側に助手 2 人が反対側に立 つ. 原則は術者の正面にモニターを 1 台用意するが，可能 であればモニターを 2 台用意することにより, 術者, 助手 ともにモニターを正面視しながら手術を円滑に行うことが できる（図 1)。

手術時にまず顎間固定用シーネの装着もしくはセルフド リリング顎間固定用スクリュー（デュアルトップオートス クリュー，ジェイル社製）の設置を上下顎に行う。顎関節 突起骨折以外に整復固定が必要な顎骨骨折があれば, 先に 嚬関節突起以外の骨折を整復固定した後に, 顎関節突起骨

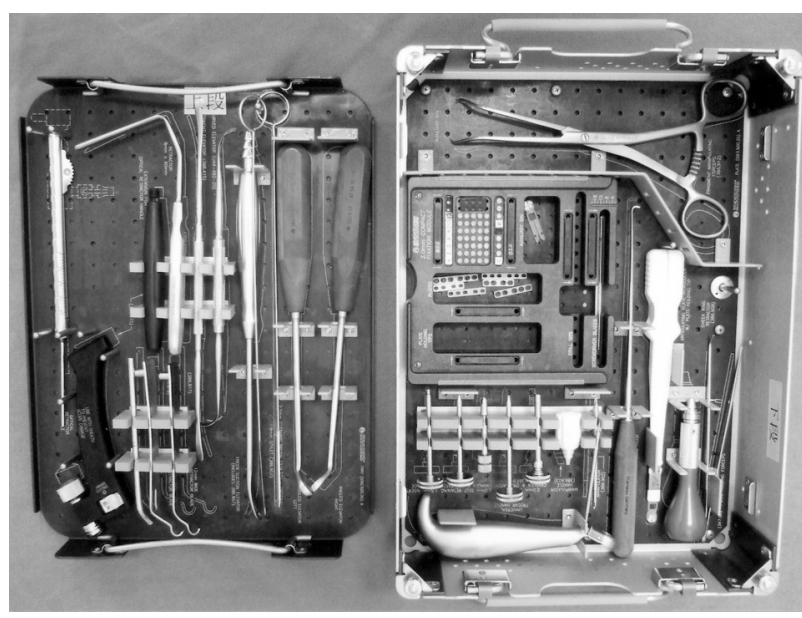

写真 2 Subcondylar/Ramus Fixation Set (SYNTHES 社 製)

$$
\text { 左：上段, 右：下段 の } 2 \text { 段からなる. }
$$

各種剥離子, リトラクター, 骨把持鉗子, ホールディン グチップ付きプレートイントロデューサー, トロッカー, プレート，スクリューなどが装備されている。

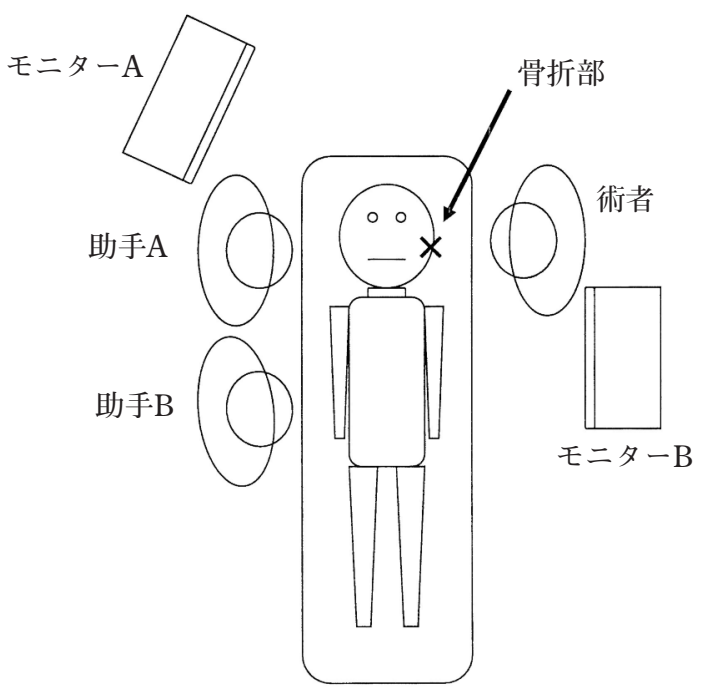

図 1 術中の術者, 助手, カメラモニターの位置関係 術者が患側に助手 2 人が反対側に立つ. 原則は術者の 正面にモニターを 1 台用意するが，可能であればモニタ 一を 2 台用意する.

折の手術に移る. 口腔内より下顎枝外斜線前縁から下顎臼 㐘部の柬肉煩移行部にかけて切開を行うが, これは下顎枝 矢状分割法（以下 SSRO）で行う切開とほぼ同様のもので ある. 骨膜下にて下顎枝外側面から下顎枝後縁, 下顎切痕 にかけて剥離をすすめ十分な術野を展開する.なおこの際, 骨膜を可能な限り損傷させずに剥離することにより出血を 最小限に抑えることが，内視鏡下の術中視野を確保するた 

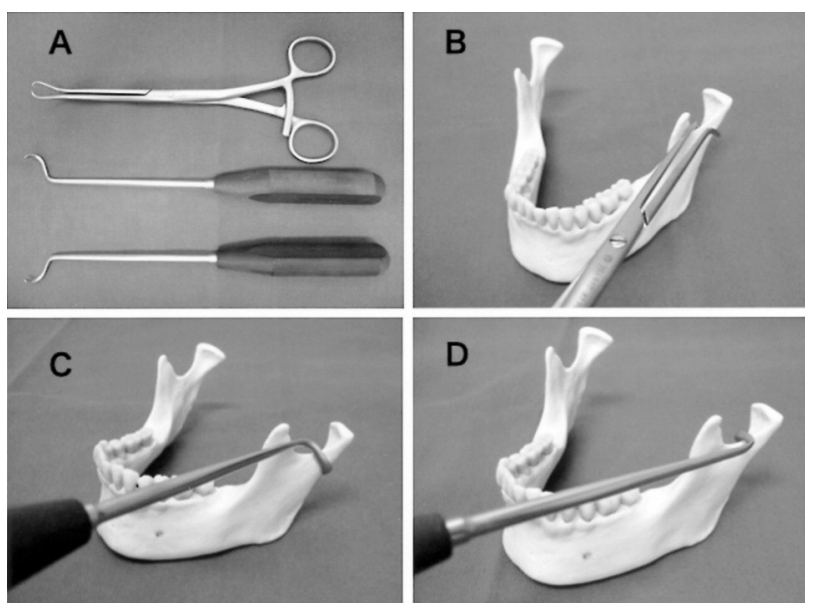

写真 3 顎関節突起骨折整復用の剥離子と骨把持鉗子

$\mathrm{A}$ ：骨把持鉗子と左右に角度の付いた剥離子.

$\mathrm{B}, \mathrm{C}, \mathrm{D}$ ：A の骨把持針子, 角度付き剥離子を用いて近位 骨片の整復を試みる。
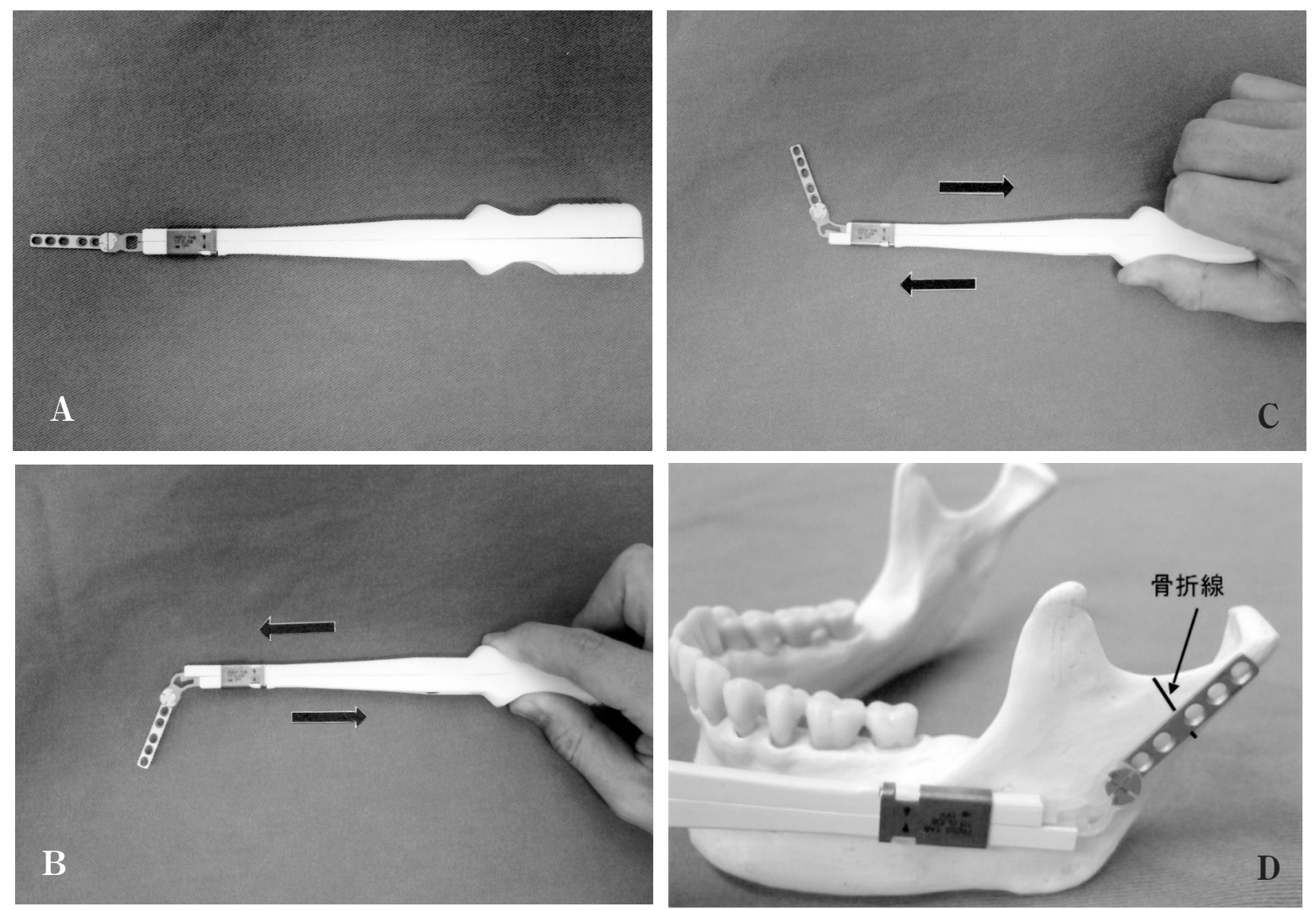

写真 4 角度調節可能なホールディングチップ付きプレートイントロデューサーでプレートを把持した状態 A, B , C : ハンドルをスライドさせることによりプレートの角度を左右に調節することが可能で，プレートを術 野に挿入し角度調整を行い適合させるのを容易にする.

D ：プレートイントロデューサーを用いて骨折部にプレートを適合させた状態. 

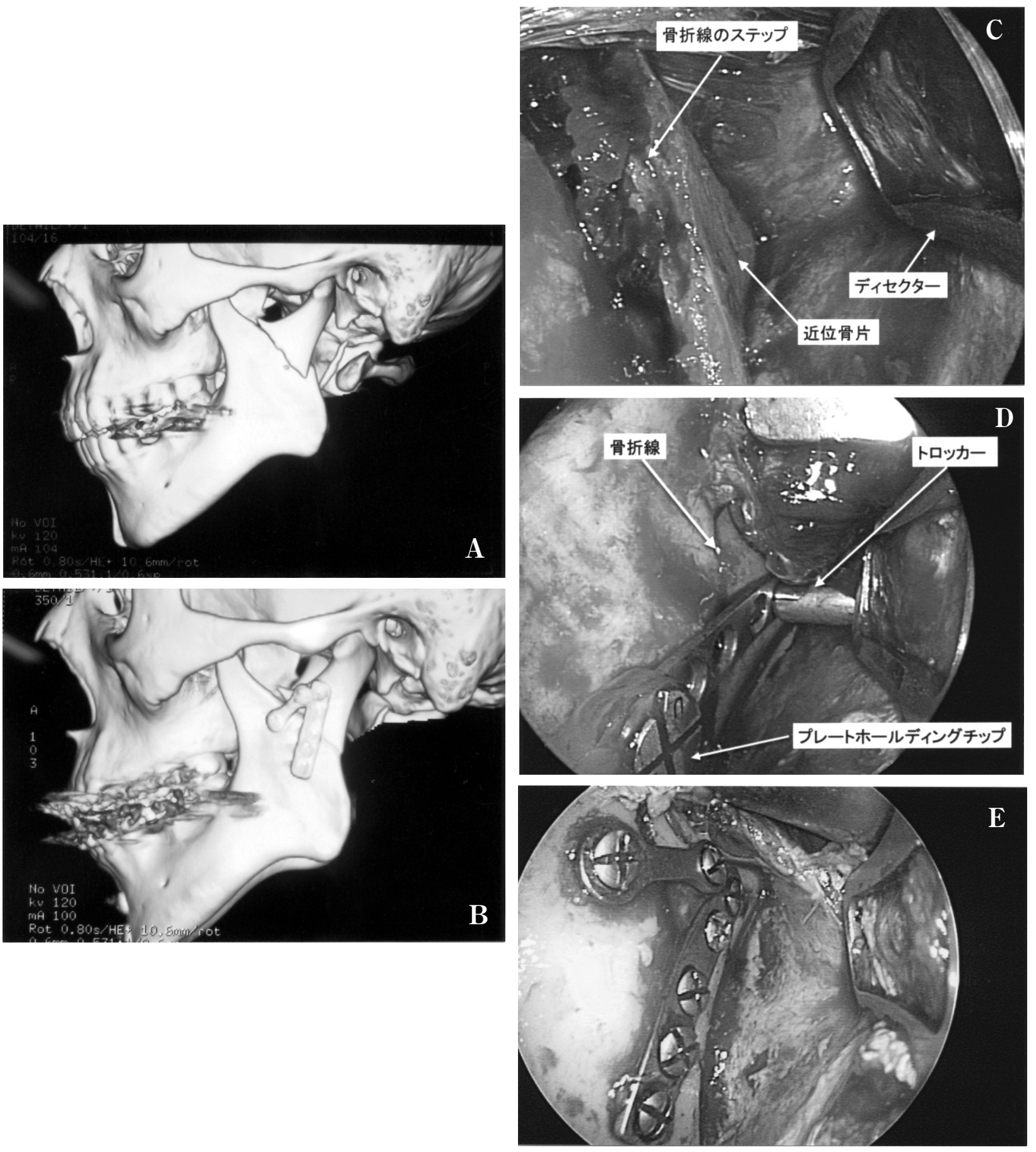

写真 5 症例 2 の CT 写真および術中写真

A : 術前 3D-CT 写真. 左側基底部に転位骨折を認める.

$\mathrm{B}$ : 術後 $3 \mathrm{D}-\mathrm{CT}$ 写真. $2.0 \mathrm{~mm}$ ミニプレート 2 枚で整復固定後.

C : 術中内視鏡像. 骨折線を鏡視下に明示したところ.

D : 術中内視鏡像. 1 枚目のプレート固定中.

$\mathrm{E} ：$ 術中内視鏡像. 近位骨片のスペースに余裕があればプレート 2 枚で整復固定を行う. 
表1 対象および結果

\begin{tabular}{|c|c|c|c|c|c|c|c|c|c|c|}
\hline 症例 & 年齢 & 性別 & 骨折部位 & 骨折状態 & $\begin{array}{l}\text { 機 能 的 } \\
\text { 予後評価 }\end{array}$ & $\begin{array}{l}\text { 形 態 的 } \\
\text { 予後評価 }\end{array}$ & 術後神経障害 & 併発顎骨骨折 & 手術時間 & 出血量 \\
\hline 1 & 19 & $\mathrm{M}$ & 左側基底部 & 転位骨折 & 完全治癒 & 完全治癒 & 左側下唇知覚鈍麻 & 上顎骨, 左側下顎体部 & 5時間14分 & 少量 \\
\hline 2 & 20 & M & 左側基底部 & 転位骨折 & 完全治癒 & 完全治癒 & 右側下唇知覚鈍麻 & 右側下顎体部 & 3 時間17分 & $170 \mathrm{ml}$ \\
\hline 3 & 24 & M & 左側下頸部 & 転位骨折 & 完全治癒 & 完全治癒 & 右側下唇知覚鈍麻 & 右側下顎体部 & 3 時間22分 & $20 \mathrm{ml}$ \\
\hline 4 & 68 & $\mathrm{~F}$ & 左側基底部 & 転位骨折 & 完全治癒 & 完全治癒 & & & 2 時間30分 & 少量 \\
\hline 5 & 27 & M & 右側下頸部 & 転位骨折 & 完全治癒 & 完全治癒 & & & 4時間15分 & $50 \mathrm{ml}$ \\
\hline 6 & 27 & $\mathrm{~F}$ & 右側下頸部 & 偏位骨折 & 完全治癒 & 完全治癒 & 右側下唇知覚鈍麻 & 右側下顎体部 & 6時間09分 & $300 \mathrm{ml}$ \\
\hline 7 & 25 & M & 右側下頸部 & 転位骨折 & 完全治癒 & 完全治癒 & & & 3時間15分 & 少量 \\
\hline 8 & 58 & M & 右側基底部 & 偏位骨折 & 完全治癒 & 完全治癒 & 右側顔面神経麻痺 & 上顎骨, 右側下顎体部 & 4時間00分 & $70 \mathrm{ml}$ \\
\hline 9 & 20 & M & 右側下頸部 & 偏位骨折 & 完全治癒 & 完全治癒 & 右側顔面神経麻痺 & & 1時間35分 & 少量 \\
\hline 10 & 18 & $\mathrm{~F}$ & 右側下頸部 & 偏位骨折 & 完全治癒 & 完全治癒 & & & 2時間15分 & 少量 \\
\hline 11 & 16 & M & 左側基底部 & 偏位骨折 & 完全治癒 & 完全治癒 & & 右側下顎体部 & 2 時間18分 & 少量 \\
\hline 12 & 28 & M & 左側下頸部 & 転位骨折 & 完全治癒 & 完全治癒 & & 右側下顎角部 & 5時間48分 & $15 \mathrm{ml}$ \\
\hline
\end{tabular}
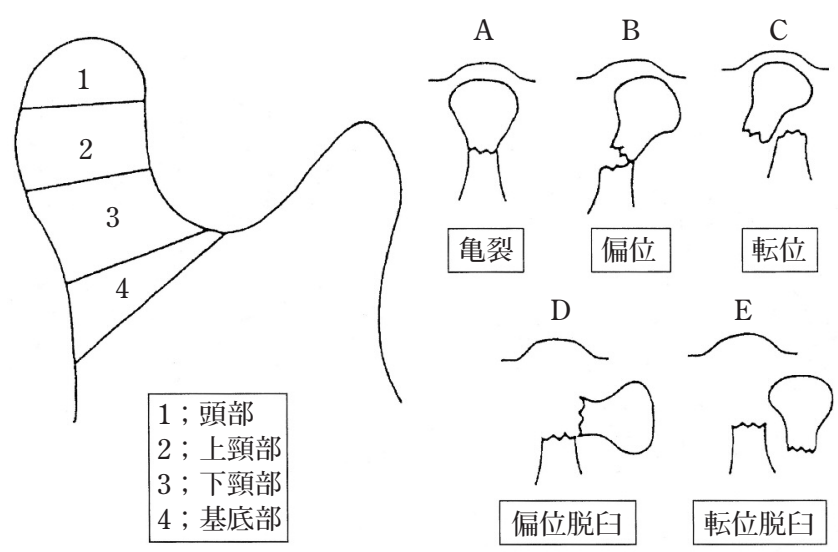

図 2 久保らの分類による顎関節突起骨折の部位および 様態 (左：部位, 右 $：$ 様態)

一ト固定を行うスペースの余裕があれば,プレートを 2 枚 用いて固定した (写真 5). プレート固定終了後に, 顎間固 定を解除，閉創し手術を終了した。

\section{対象症例と評価方法}

対象は, 2006 年 8 月から 2007 年 10 月までに本法を適用 し, 術後 6 か月以上の経過観察を行った 12 例とした. 年齢 は 16 歳から 68 歳の平均 35.0 歳で, 男性 9 例女性 3 例であ った。澦関節突起骨折は全例片側で, 下顎骨の他部位に骨 折を併発していたものが 7 例あった。

罘関節突起骨折の部位および様態は, Maclennanの分類 に改良を加えた久保ら ${ }^{6)}$ の分類（図 2）に準じ，部位は頭 部, 上頸部, 下頸部, 基底部の 4 部位に, 様態は亀裂, 偏位,
表2 中富の分類による機能的予後評価

\begin{tabular}{cl}
\hline 完全治癒 & 他覚的には開口運動時にわずかに患側に偏位す \\
& るものもあるが, 自覚的には全く障害を感じて \\
& いないもので, 開口度は 3 横指以上, 雑音, 疼痛 \\
&, 違和感の全くないものをいう.
\end{tabular}

障害 I 日常生活に不自由を感じることはないが，時折， 雑音や違和感があり, 完全治癒とはいい難いも の，ただし，疼痛，開口制限は全く意識してい ないものをいう.

障害 II 開口度 2 横指程度で, 無理な顎運動や, 強い咀 嚼に際して，疼痛や違和感を訴えることがある もので, 多くは雑音を伴っている.

障害IIIすべての顎運動が制限され，無理な顎運動を行 うと常に疼痛を感じるもの, 雑音を伴うことは 少ない.

転位，偏位脱臼，転位脱臼の 5 種類に分類した。骨折部位 は基底部骨折が 5 例, 下頸部骨折が 7 例であり, 骨折様態 は偏位骨折が 5 例, 転位骨折が 7 例であった（表 1 ). 久保 らの分類には近位骨片の転位方向は含まれていないが, 今 回の症例では全例近位骨片は外側へ転位していた。

機能的予後評価は中富 ${ }^{7)}$ の分類（表 2) に準じて, 形態 的予後評価は神谷ら ${ }^{8)}$ の X 線写真上での治癒状態につい ての分類（表 3）に準じて, 術後 6 か月経過した時点で 3 人の口腔外科医により判定した.

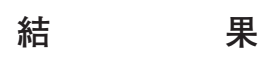

内視鏡を用いることにより十分な視野を得ることが可能 
で，すべての症例で良好な骨接合を行うことができた（写 真 5, 6). 術中出血量は少量から $300 \mathrm{ml}$ で，手術時間は 1 時間 35 分から 6 時間 9 分であったが，併発頜骨骨折の整 復を行っている症例も多く単純には比較できない. 顎関節 突起骨折の整復固定に要した時間は 1 時間から 2 時間程度

表3神谷らのX線写真上での治癒状態についての分類に よる形態学的予後評価

\begin{tabular}{|c|c|}
\hline 完全治癒 & $\begin{array}{l}\text { 健側と同様, もしくは健常人の顎関節の形態 } \\
\text { を保っているもの. }\end{array}$ \\
\hline 不完全治癒 & $\begin{array}{l}\text { 顎関節の形態が多少変形しているもの，もし } \\
\text { くは多少の偏位癒合をきたしたもの. }\end{array}$ \\
\hline 変形治癒 & $\begin{array}{l}\text { 顎関節の形態が著しく変形しているもの，も } \\
\text { しくは偏位脱臼癒合をきたしたもの. }\end{array}$ \\
\hline
\end{tabular}
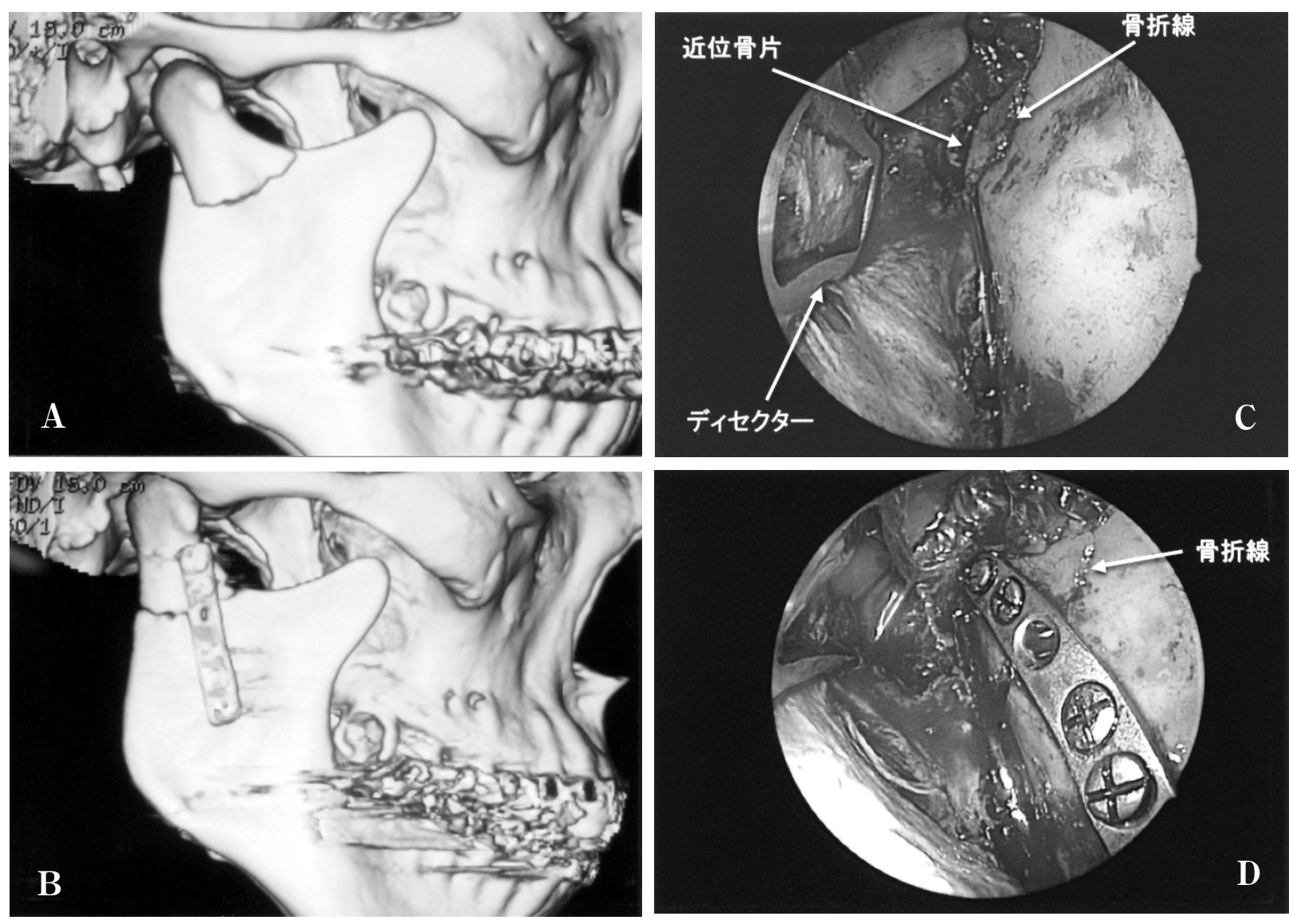

写真 6 症例 5 の CT 写真执よび術中写真

A : 術前 3D-CT 写真. 右側下頸部に転位骨折を認める.

$\mathrm{B}$ : 術後 3D-CT 写真. $2.0 \mathrm{~mm}$ ミニプレート 1 枚で整復固定後.

C：術中内視鏡像. 骨折線を鏡視下に明示したところ.

$\mathrm{D}$ ：術中内視鏡像. プレート 1 枚で整復固定終了後. 
訓練を開始した。術後 6 か月目の開口量は平均 $42.8 \mathrm{~mm}$ (37mm から $48 \mathrm{~mm})$ であった.

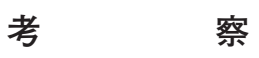

顛関節突起骨折は下顎骨骨折のなかでも発生頻度の高い 部位で，その割合は下顎骨骨折の約 $30 \%$ に五とと報 告もある ${ }^{1)}$. 顎顔面外傷を扱う口腔外科の日常臨床におい て，比較的遭遇することの多い疾患のうちの一つである. その治療法はいまだ意見の分かれるところであるが，大き く観血的治療と非観血的治療の二つに分類される. 古くか ら非観血的治療が支持されることが多かった ${ }^{6,9)}$ が，術後 の機能面, 形態面を考慮すると, 下頸部や基底部骨折では 特に観血的治療の方が非観血的治療より優れているとの報 告もある $2,7,10 \sim 12)$. 非観血的治療が支持されてきた理由 として, 従来の観血的治療の場合, 耳前部や㖽下部に比較 的大きな皮膚切開を加える必要があるため術後の皮膚瘢痕 や顔面神経損傷のリスクが高かった点が挙げられる.

一方 EAORIF では, 口腔内切開から内視鏡を挿入し，骨 折の整復も口腔内からのアプローチで行うことが可能で, 皮膚切開もプレート固定時に 2 か所トロッカーを挿入する ためのもののみですむため, 最小限の切開で十分な視野を 確保しながら手術操作を行うことができる. 術後の皮膚瘢 痕や顔面神経損傷のリスクが大幅に軽減されるために, 今 まで以上に積極的に観血的治療の適応を拡大することがで きると考えられる.

Schön ら ${ }^{3)}$ は, コントラアングルスクリュードライバー を用いることにより, 完全口腔内アプローチの手術も可能 であると報告している。しかし煩部軟組織を伸展して，ス クリューを装着したコントラアングルドライバーを操作す るための十分なスペースを確保することは，実際には非常 に困難である，下顎枝矢状分割法（SSRO）では，コントラ アングルスクリュードライバーを用いてロ内法で骨片間の 固定を行うことは多く経験するところではある ${ }^{13)}$ 。しか し, SSRO では骨片固定部位が下顎枝前縁付近であること が多いのに対し, 本法では固定部位が下顎枝後縁に近く, 煩部軟組織の伸展性がより乏しくなるために術操作が非常 に困難となる. われわれもコントラアングルスクリュード ライバーを用いてロ腔内から固定を行うことを試みたが, ドライバーを操作するための術野の垂直的空間の確保が困 難なため途中でトロッカーに切り替えた症例を経験した. この点については今後, コントラアングルドライバーの小 型化などのさらなる改良が必要であると考える.

機能的予後評価は中富 ${ }^{7)}$ の分類に, 形態的予後評価は神 谷ら ${ }^{8)}$ の分類に準じて術後 6 か月経過した時点で行った ところ，全例で良好な結果が得られた。しかし，顎関節突
起骨折のミニプレート整復固定後に下顎頭の吸収をきたし たとの報告もあり ${ }^{14,15)}$, 今後も長期的な経過観察が必要 と考えられる.

12 例中 4 例で下㐘槽神経知覚鈍麻が認められたが, 顎関 節突起骨折と同側の知覚鈍麻はそのうち 2 例であった。い ずれの症例も下顎体部に骨折を併発しており，その影響と 考えられた。 また 12 例中 2 例で術後に一過性の顔面神経 麻痺が認められた。本法とほぼ同様の切開で手術を行う SSRO での術後顔面神経麻痺が起こる原因としては, 下䪽 枝後縁へのリトラクターによる圧排, 術後の血腫, 浮腫, 動脈瘤形成などが考えられる ${ }^{16)}$ 。それらに加えて本法で は, トロッカーの挿入部位が下顎枝後縁に近いため, トロ ッカー挿入時に直接顔面神経を損傷する可能性も否定でき ない. 今回, 術後に顔面神経麻痺を生じた症例では, いず れも症状は軽度であり特に麻疩に対する治療を行うことも なく術後 1 か月以内にすみやかに麻痺が消失したことか ら, 神経への直接の損傷ではなくリトラクターによる圧迫 とそれに伴う術後の血腫や浮腫形成などが原因と考えられ た.

EAORIF の欠点としては，専用の器具が必要であること と, 内視鏡下での手術操作にも習熟を要する点が挙げられ る. 狭い術野を効果的に内視鏡でモニターに明視し, 繊細 な手術操作を行うためには術者のみならず助手にも熟練を 要する.

またすべての関節突起骨折に EAORIF が適用可能では なく, 症例を選択することが重要である. EAORIF の適応 について骨折部位で考えると, 頭部扣よび上頸部骨折では 近位骨片にプレート固定するためのスペースがなく骨折部 位の術野展開も困難なため適応外となり，下頸部および基 底部骨折が適応となる ${ }^{4,5)}$. また粉砕骨折はプレートによ る整復固定が行えないため，適応外となる.

骨折様態では一般的な観血的治療の適応として, 段差 が大きい偏位および転位ならびに脱臼症例が挙げられてい る ${ }^{8,17)}$ が，これは本法でも基本的には同様であると考え る.ただし，比較的段差の少ない偏位骨折でも従来の観血 的治療よりも低侵襲な EAORIF を行うことによって, 顎間 固定を行わずに早期の社会復帰をはたせることを考慮する と, 患者の社会的背景によっては適応となることもあると 考える. 骨折様態のみで本法の適応外となることはないが, 脱臼骨折や転位骨折のなかでも内側転位症例は手技的に難 易度が増す ${ }^{3}$ 4) と考えられる. 今回検討した症例には脱臼 症例および内側転位症例は含まれていないため, 今後さら なる検討を要する. 年齢については, 14 ～16歳前後まで は非観血的治療により下顎頭の修復再形成が良好になされ ることが報告されており ${ }^{6)}$, EAORIF の適応もお扎よそ 16 歳以上になると考える。 
今回経験したすべての症例で結果的に良好な整復固定を 行うことができ，顎関節突起骨折に対する内視鏡支援下で の観血的整復固定術は非常に有用な治療方法であると考え られた。しかし，すべての症例に対して EAORIFを適用す るという訳ではなく, 骨折部位や様態によって非観血的治 療や口腔外アプローチでの観血的治療法も検討し, 患者に とって最良の方法を選択することが重要であると思われ た.

\section{引用 文 献}

1) Ellis, E., Moos, K.F., et al.: Ten years of mandibular fractures: An analysis of 2,137 cases. Oral Surg 59: 120-129 1985.

2) 額田純一郎, 加納康行, 他: 下顎骨関節突起骨折の 保存, 外科治療の臨床成績比較. 日災医会誌 46: 5455481998.

3) Schön, R., Fakler, O., et al.: Five-year experience with the transoral endoscopically assisted treatment of displaced condylar mandible fractures. Plast Reconstr Surg 116: 44-50 2005.

4) Mueller, R., Czerwinski, M., et al.: Condylar fracture repair: Use of the endscope to advance traditional treatment philosophy. Facial Plast Surg Clin N Am 14: 1-9 2006.

5）高 済石, 竹信俊彦, 他：内視鏡を併用した下顎骨 関節突起基底部骨折観血的整復固定術の 1 例. 日口 外傷誌 3: 83-86 2004.

6) 久保四郎, 村橋 護, 他 : 顎関節突起骨折 124 症例 に関する臨床的検討, 特にその分類について. 日ロ 外誌 29: 1794-1805 1983.
7）中富憲次郎：顎関節突起骨折の臨床的研究. 口科誌 38: 406-415 1985.

8）神谷裕司，日下雅裕，他：下顎骨関節突起骨折にお けるキルシュナー鋼線使用症例の予後について．日 口外誌 37: 1165-1172 1991.

9) Maclennan, W.D.: Consideration of 180 cases of typical fractures of the mandibular condylar process. Br J Plast Surg 5: 122-132 1952.

10) Ellis, E. and Dean, J.: Rigid fixation of mandibular condyle fractures. Oral Surg Oral Med Oral Pathol 76: 6-15 1993

11) Zide, M.F. and Kent, J.N.: Indications for open reduction of mandibular condyle fractures. J Oral Maxillofac Surg 41: 89-98 1983.

12) Widmark, G., Bagenholm, T., et al.: Open reduction of subcondylar fractures. Int J Oral Maxillofac Surg 25: 107-111 1996 .

13）石井宏昭，三井周子，他：ミニプレート固定を併用 した下顎枝矢状分割術の臨床的検討。日顎変形誌 14: 180-185 2004

14）土川幸三：頼関節突起骨折の治療：顎機能の回復を めざして. 新潟医会誌 112: 110-114 1998.

15） lizuka, T., Lindqvist, C., et al.: Severe bone resorption and osteoarthrosis after miniplate fixation of high condylar fractures. A clinical and radiologic study of thirteen patients. Oral Surg Oral Med Oral Pathol 72: 400-407 1991.

16) Dendy, R.A.: Facial nerve paralysis following sagittal split mandibular osteotomy: a case report. Br J Oral Surg 11: 101-105 1973

17）竹信俊彦，古木良彦，他：䪽関節突起骨折に対する Lag Screw Osteosynthesis 法の検討。日口外誌 43: 51-53 1997. 